\title{
Pemberian Jus Mentimun (Cucumis Sativus. Linn) Pada Penderita Hipertensi Wanita Usia Produktif
}

\author{
Zul Fikar Ahmad ${ }^{1 *}$, Siti Surya Indah Nurdin ${ }^{2}$
}

${ }^{1}$ Jurusan Kesehatan Masyarakat, Fakultas Olah Raga dan Kesehatan, Universitas Negeri Gorontalo, Jl. Jenderal Sudirman No. 06 Kota Gorontalo 96128, Indonesia

2 Jurusan Kebidanan, Fakultas Ilmu Kesehatan, Universitas Muhammadiyah Gorontalo, Jl. Prof. H. Mansoer Pateda64, Gorontalo 96181, Indonesia

*Penulis Korespondensi, Email: zulfikar@ung.ac.id

\section{ABSTRAK}

Hipertensi merupakan salah satu masalah kesehatan masyarakat yang menyebabkan tingginya tingkat kematian dan ketidakmampuan mencapai usia harapan hidup. Penelitian ini bertujuan untuk menilai pengaruh pemberian mentimun (Cucumis sativus Linn) dalam bentuk jus terhadap tekanan darah pada penderita hipertensi. Penelitian ini menggunakan desain quasi eksperimen dengan rancangan Non-Randomized Control Group Pre-test Post-test Design. Populasi penelitian ini adalah penderita pra-hipertensi dan hipertensi tingkat I wanita usia produktif di wilayah kerja Puskesmas Telaga Biru Kabupaten Gorontalo. Sampel sebanyak 42. Data dianalisis menggunakan Paired Samples $t$ Test dan Independent-samples $t$ Test. Hasil penelitian menunjukkan bahwa pemberian jus mentimun tanpa biji menurunkan tekanan darah sistolik sebesar 18,524 $\mathrm{mmHg}(\mathrm{p}=0,000)$, dan tekanan darah diastolik sebesar 8,905 $\mathrm{mmHg}(\mathrm{p}=0,000)$. Pemberiuan jus mentimun dengan biji menurunkan tekanan darah sistolik sebesar 15,952 $\mathrm{mmHg}$ dan tekanan darah diastolik sebesar 7,571 $\mathrm{mmHg}(\mathrm{p}=0,000)$. Tidak ditemukan perbedaan penurunan tekanan darah sistolik $(p=0,257)$ dan tekanan darah diastolik ( $p=0,414)$ antara pemberian jus mentimun tanpa biji dengan jus mentimun dengan biji. Dengan demikian pemberian jus mentimun dapat menurunkan tekanan darah.

Kata Kunci: Hipertensi, Mentimun

$\begin{array}{lcc}\text { Diterima: } & \text { Disetujui: } & \text { Online: } \\ \text { 14-07-2019 } & 16-08-2019 & 12-09-2019\end{array}$


ABSTRACT

Hypertension is one of the public health problems that cause mortality and inability to reach life expectancy. The aim of the research is to assess the effect of juice cucumber (Cucumis sativus Linn) on blood pressure of hypertension patients. The research used a quasi experiment design with NonRandomized Control Group Pre-test Post-test Design. The populations include pre-hypertension and hypertension grade I patients of women childbearing age in the working area of Telaga Biru Health Centre of Gorontalo Regency. The samples were 42 pre-hypertension and hypertension grade I patients. They were divided in to two groups, a group given cucumber juice without seeds and another group given cucumber juice with seeds. The data were analyzed using Paired-samples $t$ Test and Independentsamples $t$ Test. The result of the study indicate that giving cucumber juice without seeds decrease of systolic blood pressure by $18,524 \mathrm{mmHg}(p=0,000)$ and decrease diastolic blood pressure by 8,905 $m m H g(p=0,000)$. Giving cucumber juice with seeds could decrease systolic blood pressure by 15,952 $\mathrm{mmHg}(p=0,000)$ and diastolic blood pressure by $7,571 \mathrm{mmHg}(p=0,000)$. There was no difference between giving cucumber juice without seeds and giving cucumber juice with seeds in the decrease of systolic blood pressure $(p=0,257)$ and the decrease of diastolic blood pressure $(p=0,414)$. This shows that giving cucumber juice can decrease blood pressure.

\begin{tabular}{ccc}
\hline Keywords: Hypertension, Cucumber & & \\
\hline Received: & Accepted: & Online: \\
2019-07-14 & $2019-08-16$ & $2019-09-12$ \\
\hline
\end{tabular}

\section{Pendahuluan}

Penyakit tidak menular merupakan penyebab kematian terbesar diseluruh dunia. Disamping kematian, penyakit ini juga menyebabkan tingginya tingkat morbiditas dan kecacatan. Kematian akibat Non-Communicable Disease (NCD) meningkat $14,1 \%$ atau sekitar 39,8 juta jiwa sejak tahun 2005 sampai tahun 2015. Salah satu penyakit yang turut menyumbangkan angka kematian akibat penyakit tidak menular adalah penyakit hipertensi [1]. Di seluruh dunia, peningkatan tekanan darah diperkirakan menyebabkan 7,5 juta kematian, sekitar $12,8 \%$ dari total seluruh kematian. Hipertensi menyumbang 57 juta ketidakmampuan mencapai usia harapan hidup[2]. Penderita hipertensi di Provinsi Gorontalo masih berada di atas rata-rata nasional $(9,4 \%)$ [3].

Pengobatan hipertensi dapat dilakukan dengan cara farmakologis yaitu dengan memberikan obat-obatan anti hipertensi dan non farmakologis dengan cara modifikasi gaya hidup [4]. Pendekatan berbasis tanaman dan buah juga merupakan salah satu pendekatan pengobatan hipertensi yang berkembang saat ini. Selain karena murah, efek yang dihasilkan juga lebih baik dibandingkan obat kimia meskipun memerlukan waktu yang sedikit lebih lama bila dibandingkan dengan yang kimia. Salah satu sayuran yang dapat menurunkan tekanan darah adalah mentimun (Cucumis sativus Linn). Mengkonsumsi mentimun dalam bentuk jus dapat menurunkan tekanan darah [5].

Tingginya kandungan kalium, menjadikan mentimun sebagai salah satu pilihan dalam upaya terapi nonfarmakologis penyakit hipertensi. Asupan kalium terhadap tekanan darah, menemukan bahwa asupan kalium berhubungan dengan tekanan darah sistolik dan tekanan darah diastolik dengan arah korelasi negatif, hal tersebut menunjukkan bahwa semakin tinggi konsumsi kalium maka dapat menurunkan tekanan darah pada pasien hipertensi [6]. Selain Kalium, mentimun juga mengandung magnesium yang berperan dalam menurunkan tekanan darah suplementasi magnesium $(\mathrm{Mg})$ secara signifikan mengurangi tekanan darah [1]. 
Melihat permasalahan hipertensi yang kompleks, dan perkembangan produk dari bahan makanan dan tumbuhan yang semakin nyata dirasakan manfaatnya bagi kesehatan khususnya dalam pengobatan hipertensi berbasis buah dan sayur sebagai alteratif pengobatan dan pencegahan yang tanpa efek samping. Sehingga diperlukan adanya penilaian terhadap sejauh mana pengobatan berbasis buah dan sayur mempengaruhi tekanan darah. Adapun tujuan penelitian ini adalah untuk menilai pengaruh pemberian jus mentimun (Cucumis sativus Linn) terhadap penurunan tekanan darah penderita hipertensi pada usia dewasa.

\section{Metode}

\subsection{Rancangan Penelitian}

Penelitian ini dilaksanakan di Wilayah Kerja Puskesmas Telaga Biru, Kabupaten Gorontalo dengan menggunakan rancangan Quasi Experiment (Eksperimen Semu) dengan rancangan penelitian yang digunakan adalah Non-Randomized Control Group Pretest Post-test Design. Penelitian ini terdiri dari dua kelompok intervensi, yaitu kelompok I dengan perlakuan jus mentimun tanpa biji, dan kelompok II dengan perlakuan jus mentimun dengan biji.

\subsection{Populasi dan Sampel}

Populasi dalam penelitian ini adalah seluruh wanita usia produktif yang menderita prahipertensi dan hipertensi tingkat 1 yang berada di Wilayah Kerja Puskesmas Telaga Biru. Jumlah sampel sebanyak 42 orang yang dipilih secara Purposive sampling yang memenuhi kriteria yang ditentukan yaitu menderita pra-hipertensi atau hipertensi tingkat I, tidak sedang mengkonsumsi obat kimia maupun obat tradisional penurun tekanan darah ditentukan, tidak menderita penyakit komplikasi seperti Diabetes Mellitus, Jantung, Stroke, Gagal Ginjal berdasarkan diagnosa dokter, dan tidak sedang dalam keadaan hamil atau menyusui.

\subsection{Analisis Data}

Pengolahan data dilakukan dengan menggunakan program computer SPSS versi 25 untuk melakukan analisis data dengan uji univariat dan bivariat. Uji univariat dilakukan pada karakteristik umum responden untuk melihat gambaran umum distribusi dan frekuensinya. Uji bivariat dilakukan dengan membandingkan hasil tekanan darah sebelum dan sesudah diberikan jus mentimun dengan menggunakan uji t berpasangan (Paired Samples $t$ Test) dan uji Independent-samples $t$ Tes untuk menguji perbedaan perubahan tekanan darah pada kedua kelompok yang diberi perlakuan jus mentimun yang berbeda.

\subsection{Bahan}

Mentimun yang digunakan adalah mentimun biasa (Cucumis sativus Linn) dengan tingkat kematangan dan warna yang seragam. Dikategorikan matang ketika mentimun mentimun berumur 40-50 hari. Beratnya minimal 200 gram dan panjang minimal $20 \mathrm{~cm}$. Mentimun di Buat dalam bentuk jus. 


\section{Hasil dan Pembahasan}

\subsection{Karakteristik Umum}

Tabel 1 menunjukkan bahwa kelompok umur responden tertinggi adalah kelompok umur 41 - 45 tahun pada kedua kelompok atau sebanyak 61,9\% pada kelompok I dan $52,4 \%$ pada kelompok II. Distribusi tingkat pendidikan responden tertinggi pada kelompok I adalah Sekolah Menengah Atas yaitu sebanyak 33,3\% dan Sekolah Menengah Pertama pada kelompok II, yaitu sebanyak 33,3\%. Berdasarkan pekerjaan distribusi responden tertinggi pada kelompok I adalah pekerjaan petani/ buruh dan lainnya yaitu sebanyak $28,6 \%$ dan pada kelompok II pekerjaan responden lainnya menempati urutan tertinggi, yaitu sebanyak $42,9 \%$.

Tabel 1. Karakteristik umum responden

\begin{tabular}{lcccc}
\hline \multicolumn{1}{c}{ Karakteristik } & \multicolumn{2}{c}{ Kelompok I } & \multicolumn{2}{c}{ Kelompok II } \\
& $\mathrm{n}$ & $\%$ & $\mathrm{n}$ & $\%$ \\
\hline Kelompok Umur & & & & \\
26-30 tahun & - & - & 2 & 9,5 \\
31-35 tahun & 2 & 9,5 & 3 & 14,3 \\
36-40 tahun & 6 & 28,6 & 5 & 23,8 \\
41-45 tahun & 13 & 61,9 & 11 & 52,4 \\
\hline Tingkat Pendidikan & 1 & 4,8 & 2 & \\
Tidak Sekolah & 6 & 28,6 & 2 & 9,5 \\
SD & 5 & 23,8 & 7 & 33,3 \\
SMP & 7 & 33,3 & 5 & 23,8 \\
SMA & 2 & 9,5 & 5 & 23,8 \\
PT & & & & \\
Pekerjaan & & & & \\
Pegawai & 4 & 19 & 6 & 28,6 \\
Wiraswasta / & 5 & 23,8 & 3 & 14,3 \\
$\quad$ Pedagang & 6 & 28,6 & 3 & 14,3 \\
Petani / Buruh & 6 & 28,6 & 9 & 42,9 \\
Lainnya & & & & \\
\hline
\end{tabular}

Sumber : Data Primer 2019

\subsection{Gambaran Tekanan Darah Responden}

Tabel 2 menunjukkan bahwa rata-rata tekanan darah sistolik dan diastolik pada kelompok I menunjukkan bahwa rata-rata tekanan darah sistolik dan diastolik sebelum diberikan perlakuan jus mentimun tanpa biji adalah $146,1 \mathrm{mmHg}$ dan $92,9 \mathrm{mmHg}$. Setelah diberikan perlakuan, rata-rata tekanan darah responden adalah 127,6 $\mathrm{mmHg}$ untuk tekanan darah sistolik, dan $83,7 \mathrm{mmHg}$ untuk tekanan darah diastolik.

Pada Kelompok II, rata-rata tekanan darah sistolik dan diastolik sebelum diberikan perlakuan jus mentimun dengan biji adalah 144,4 $\mathrm{mmHg}$ dan 90,8 $\mathrm{mmHg}$. Setelah diberikan perlakuan, rata-rata tekanan darah responden adalah 128,5 $\mathrm{mmHg}$ untuk tekanan darah sistolik, dan 83,2 mmHg untuk tekanan darah diastolik. 
Tabel 2. Gambaran tekanan darah responden

\begin{tabular}{lrr}
\hline \multicolumn{1}{c}{ Tekanan Darah } & Min - Max & Mean \pm Std. Deviasi \\
\hline Kelompok I & & \\
Sistolik Sblm Perlakuan & $132-159$ & $146.1 \pm 7.8$ \\
Diastolik Sblm Perlakuan & $86-99$ & $92.8 \pm 3.7$ \\
Sistolik Stlh Perlakuan & $110-144$ & $127.6 \pm 9.1$ \\
Diastolik Stlh Perlakuan & $74-93$ & $83.7 \pm 4.9$ \\
Kelompok II & & \\
Sistolik Sblm Perlakuan & $131-159$ & $144.4 \pm 9.4$ \\
Diastolik Sblm Perlakuan & $85-98$ & $90.8 \pm 4.6$ \\
Sistolik Stlh Perlakuan & $112-153$ & $128.5 \pm 9.6$ \\
Diastolik Stlh Perlakuan & $74-92$ & $83.2 \pm 4.6$ \\
\hline
\end{tabular}

Sumber : Data Primer, 2019

\subsection{Mentimun Terhadap tekanan Darah}

Tabel 3 menunjukkan bahwa nilai rata-rata penurunan tekanan darah sistolik pada kelompok I sebesar $18,5 \mathrm{mmHg}$ dan untuk tekanan darah diastolik mengalami penurunan sebesar $8,9 \mathrm{mmHg}$, dengan nilai $\mathrm{p}$ masing-masing 0,00 . Nilai $\mathrm{p}$ untuk kelompok $\mathrm{I}<\alpha=0,05$ sehingga terjadi penurunan tekanan darah sistolik maupun diastolik secara signifikan pada kelompok I. Rata-rata penurunan tekanan darah sistolik pada kelompok II sebesar $15,9 \mathrm{mmHg}$, dengan nilai $\mathrm{p}=0,00$ dan tekanan darah diastolik mengalami penurunan sebesar $7,5 \mathrm{mmHg}$, dengan nilai $\mathrm{p}=0,00$. Nilai $\mathrm{p}$ untuk kelompok II $<a=0,05$ sehingga secara statistik penurunan tekanan darah sistolik maupun diastolik dianggap signifikan pada kelompok II.

Tabel 3. Penurunan tekanan darah masing-masing kelompok

\begin{tabular}{lccccc}
\hline \multicolumn{1}{c}{ Tekanan Darah } & $\begin{array}{c}\text { Mean } \pm \text { Std. } \\
\text { Deviasi }\end{array}$ & $\begin{array}{c}95 \% \text { CI } \\
\text { Lower }\end{array}$ & Upper & t & \multirow{2}{*}{ Nilai p } \\
\hline $\begin{array}{l}\text { Kelompok I } \\
\quad \text { Sistolik Sblm - Sistolik }\end{array}$ & $18,5 \pm 8,1$ & 14,8 & 22.2 & 10.460 & .000 \\
$\begin{array}{l}\text { Stlh Perlakuan } \\
\text { Diastolik Sblm - Diastolik }\end{array}$ & $9.1 \pm 4.7$ & 6.9 & 11.3 & 8.847 & .000 \\
$\begin{array}{l}\text { Stlh Perlakuan } \\
\text { Kelompok II }\end{array}$ & & & & & \\
$\quad \begin{array}{l}\text { Sistolik Sblm - Sistolik Stlh } \\
\text { Perlakuan }\end{array}$ & $15.9 \pm 7.7$ & 12.4 & 19.4 & 9.450 & .000 \\
$\begin{array}{l}\text { Diastolik Sblm - Diastolik } \\
\text { Stlh I Perlakuan }\end{array}$ & $7.5 \pm 4.2$ & 5.6 & 9.5 & 8.281 & .000 \\
\hline Sumber : Data Primer, 2019 & & & & &
\end{tabular}

Tabel 4 berikut menunjukkan bahwa tidak terdapat perbedaan penurunan tekanan darah pada kedua kelompok intervensi yaitu kelompok I yang diberi perlakuan jus mentimun tanpa biji dengan kelompok II yang diberi perlakuan jus mentimun dengan biji, dengan nilai $\mathrm{p}=0,257>\mathrm{a}=0,05$ untuk tekanan darah sistolik, dan untuk tekanan darah diastolik diperoleh nilai $p=0,414>a=0,05$. 
Tabel 4. Perbedaan penurunan tekanan darah kelompok I dan II

\begin{tabular}{|c|c|c|c|c|}
\hline \multirow{2}{*}{$\begin{array}{c}\text { Tekanan } \\
\text { Darah }\end{array}$} & \multicolumn{2}{|c|}{ Mean \pm SD } & \multirow[b]{2}{*}{ Nilai t } & \multirow{2}{*}{ Nilai $p$} \\
\hline & Kelompok I & Kelompok II & & \\
\hline Sistolik & $18,5 \pm 9,1$ & $15,9 \pm 7,5$ & - & 0,257 \\
\hline Diastolik & $8,1 \pm 4,7$ & $7,5 \pm 4,1$ & 1,139 & 0,414 \\
\hline
\end{tabular}

Sumber : Data Primer, 2019

Hasil yang diperoleh sejalan dengan penelitian yang dilakukan Ekanto dkk bahwa dengan mengkonsumsi jus mentimun 200 gram dengan air sebanyak 150 cc setiap hari selama tujuh hari berturut-turut, dapat menurunkan tekanan darah sistolik setelah minum jus mentimun adalah $136,82 \mathrm{mmHg}( \pm 9,816)$, lebih rendah dari tekanan darah sistolik sebelum minum jus mentimun adalah $167,7 \mathrm{mmHg}( \pm 6,068)$ dengan $\mathrm{p}<0,01)$ [7]. Hasil yang sama diperoleh dari penelitian yang dilakukan Aisyah dan Probosari (2014), bahwa dengan mengkonsumsi satu gelas $(250 \mathrm{ml})$ yang mengandung 100 gram mentimun selama tujuh hari berturut-turut, secara signifikan dapat menurunkan tekanan darah sistolik sebesar $16,00+8,062 \mathrm{mmHg}(\mathrm{p}=0,000)$ dan tekanan darah diastolik sebesar $6,67+6,726 \mathrm{mmHg}(\mathrm{p}=0,002)[8]$.

Mentimun dapat menurunkan tekanan darah karena kandungan kalium dan magnesiumnya yang tinggi. Kalium yang terkandung pada mentimun bersifat vasoaktif. Kalium dapat menimbulkan vasodilatasi sebagai hasil dari hiperpolarisasi sel otot polos vaskular yang terjadi akibat stimulasi kalium pada pompa natrium $(\mathrm{Na}+)$ / kalium $(\mathrm{K}+)$ dan juga mengaktifkan Kir channels. Ion kalium juga dilepaskan oleh sel endotel sebagai respon terhadap mediator neurohumoral dan stress fisik, hasilnya akan terjadi relaksasi endotel. Kalium yang terkandung pada mentimun juga menghindari terjadinya retensi natrium sehingga memberikan efek penurunan tekanan darah [9]. Kalium juga dapat mencegah terjadinya Angiotensin II yang merupakan vasokonstriktor kuat yang menyebabkan kenaikan tekanan darah. Kalium mengurangi pelepasan aldosteron dari zona glomerulosa kelenjar adrenal, yang menghasilkan peningkatan tekanan darah lebih lanjut terkait dengan retensi natrium dan air [10].

Efek antihipertensi yang terkandung pada mentimun karena kandungan kalium ini dapat melalui lebih dari satu mekanisme. Tidak hanya karena menstimulasi pompa natrium, kalium, dan Adenosina trifosfat (ATPase) pada sel otot polos pembuluh darah dan saraf terminal adrenergik yang menghasilkan vasodilatasi serta menginduksi relaksasi endotel, pada konsumsi jangka panjang dapat memicu mekanisme yang disebut adaptasi kalium yang mampu meningkatkan jumlah molekul enzim [11]. Adaptasi kalium ini akan menjaga stabilitas konsentrasi kalium dalam plasma sehingga mampu menunda terjadinya hipertensi pada subjek yang mengkonsumsi kalium [12]. Penelitian yang dilakukan oleh Zhang et al (2016) menunjukkan bahwa dengan mengkonsumsi natrium yang tinggi secara signifikan terkait dengan tekanan darah sistolik dengan kenaikan 1,04 mmHg (95\% CI, 0,27-1,82) dan mengkonsumsi konsumsi kalium $1.000 \mathrm{mg} /$ hari menurunkan tekanan darah sebear 1,24 mmHg (95\% CI, 0,31-2,70) [13]. Hasil yang sama diperoleh Riyadi dkk (2016) menunjukkan bahwa bahwa asupan natrium dan kalium memiliki hubungan yang signifikan terhadap kejadian hipertensi esensial. Asupan tinggi natrium (OR: 3,43; CI 95\%:1,09-10,77). Di sisi lain, asupan tinggi kalium yang mengurangi risiko pada terjadinya hipertensi esensial (OR: 0,24; CI 95\%: 0,07-0,84) atau faktor protektif terhadap risiko kejadian hipertensi [14].

Selain Kalium, kandungan magnesium yang tinggi dalm mentimun juga turut berperan dalam menurunkan tekanan darah. Magnesium dan kalsium memiliki hubungan yang 
terbalik dalam system kardiovaskuler [15]. Peningkatan kadar magnesium ekstraseluler menghambat masuknya kalsium. Sebaliknya, kurangnya magnesium ekstraseluler mengaktifkan masuknya kalsium melalui saluran kalsium. Rendahnya konsentrasi magnesium intraselular menstimulasi Inositol-trisphosphate- (IP3-) untuk mobilisasi kalsium intraseluler dan mengurangi Ca2 + -ATPase. Dengan demikian, kalsium dan sarkoplasma reticular kalsium reuptake berkurang, menyebabkan akumulasi sitosol kalsium dan peningkatan konsentrasi kalsium intraseluler, yang merupakan faktor penting untuk vasokonstriksi. Peningkatan konsentrasi magnesium intraseluler, dan menurunnya konsentrasi kalsium intraseluler, menyebabkan terjadinya vasodilatasi [16].

Tindakan magnesium sebagai blocker saluran kalsium juga dapat membantu untuk mengurangi pelepasan kalsium dan sehingga mengurangi resistensi pembuluh darah. Selain itu, magnesium juga mengaktifkan pompa natrium, kalium, dan ATPase yang mengontrol keseimbangan mineral yang berkontribusi terhadap homeostasis elektrolit dalam sel [17]. Konsentrasi intraselular magnesium tergantung pada tingkat ekstraseluler, dan masuknya melalui saluran kalsium tergantung tegangan. Magnesium ekstraseluler secara kompetitif dapat menghambat saluran kalsium dan menentukan berkurangnya sekresi insulin. Penghambatan terhadap kalsium tidak terjadi bila tidak ada magnesium dalam ruang ekstraselular, sehingga sekresi insulin yang lebih tinggi [18].

Penelitian menunjukkan bahwa dengan suplementasi magnesium sebanyak 368 gram setiap hari, dapat menurunkan tekanan darah sistolik 2,00 $\mathrm{mmHg}$ (Interval kepercayaan $95 \%, 0,43-3,58)$ dan tekanan darah diastolik sebesar 1,78 $\mathrm{mmHg}$ (95\% interval kepercayaan, 0,73 -2,82) [13]. Hasil yang sama diperoleh Bullarbo et al (2013) bahwa dengan mengkonsumsi $300 \mathrm{mg}$ magnesium setiap hari dapat menurunkan tekanan darah diastolik $\geq 15 \mathrm{mmHg}$ secara signifikan lebih rendah pada kelompok magnesium dibandingkan dengan mereka yang memiliki asupan magnesium yang kurang $(p=0,011)$ [19].

\section{Kesimpulan}

Pemberian jus mentimun tanpa biji maupun jus mentimun dengan biji secara signifikan dapat menurunkan tekanan darah penderita hipertensi, namun tidak terdapat perbedaan penurunan tekanan darah antara mengkonsumsi jus mentimun tanpa biji maupun jus mentimun dengan biji.

\section{Referensi}

[1] Wang H, Naghavi M et al. (2016). Global, regional, and national life expectancy, all-cause mortality, and cause-specific mortality for 249 causes of death, 19802015: a systematic analysis for the Global Burden of Disease Study 2015. Lancet.

[2] WHO. Raised Blood Plessure [Internet]. (2018). Available from: http://www.who.int/gho/ncd/risk_factors/blood_pressure_prevalence_text/e $\mathrm{n} /$

[3] Kemenkes. (2018). Hasil Utama Riset Kesehatan Dasar tahun 2018. Kementrian Kesehatan Republik Indonesia, Badan Pengembangan dan Penelitian Kesehatan.

[4] Weber MA, et al. (2015). Clinical Practice Guidelines for the Management of Hypertension in the Community. Journal Clinical Hypertension.

[5] Aminah D dan Krisnawati MH. 2(018). Penurunan Tekanan Darah Menggunakan 
Jus Mentimun. J Keperawatan, 6(1):28-32.

[6] Kusumastuty I, Widyani D, Sri Wahyuni E. (2016). Asupan Protein dan Kalium Berhubungan dengan Penurunan Tekanan Darah Pasien Hipertensi Rawat Jalan (Protein and Potassium Intake Related to Decreased Blood Pressure in Outclinic Hypertensive Patients). Indonesian Journal Human Nutrition.

[7] Ekanto B, Istiqomah I, Anisa U. (2015). Pemberian Mentimun Terhadap Tekanan Darah Sistolik dan Diastolik pada Wanita Lansia Hipertensi. Jurnal Keperawatan Karya Bhakti, 1(1):25-31.

[8] Aisyah A, dan Probosari E. (2014) Pengaruh Pemberian Jus Mentimun (Cucumis sativus 1) Terhadap Penurunan Tekanan Darah Pada Penderita Hipertensi Wanita Usia 40-60 Tahun. Diponegoro University.

[9] Dongfeng, Gu et al. (2013). Reproducibility of blood pressure responses to dietary sodium and potassium interventions: The GenSalt study. Hypertension.

[10] Takahashi H, et. al. (2011). The central mechanism underlying hypertension: A review of the roles of sodium ions, epithelial sodium channels, the reninangiotensin-aldosterone system, oxidative stress and endogenous digitalis in the brain. Hypertension Research.

[11] Adrogué H. J., dan Madias N. (2014). Sodium surfeit and potassium deficit: Keys to the pathogenesis of hypertension. J Am Soc Hypertens, (8):203-13.

[12] Terker AS, et al. (2015). Potassium modulates electrolyte balance and blood pressure through effects on distal cell voltage and chloride. Cell Metabolism.

[13] Zhang X, et al. (2016). Effects of Magnesium Supplementation on Blood Pressure. Hypertension.

[14] Riyadi A, Wiyono P, Budiningsari RD. (2007). Asupan gizi dan status gizi sebagai faktor risiko hipertensi esensial pada lansia di Puskesmas Curup dan Perumnas Kabupaten Rejang Lebong Propinsi Bengkulu. J Gizi Klinik Indonesia.

[15] Champagne CM. (2008). Magnesium in hypertension, cardiovascular disease, metabolic syndrome, and other conditions: A review. Nutrition in Clinical Practice.

[16] Sontia B, dan Touyz RM. (2007). Role of magnesium in hypertension. Archves of Biochemistry Biophysics.

[17] Gröber U, Schmidt J, Kisters K. (2015). Magnesium in prevention and therapy. Nutrients.

[18] Cunha AR, et. al. (2012). Magnesium and vascular changes in hypertension. International Journal of Hypertension.

[19] Bullarbo M, et al. (2013). Magnesium supplementation to prevent high blood pressure in pregnancy: A randomised placebo control trial. Arch Gynecol Obstet. 